\title{
Optimasi Biaya dan Waktu Proyek Konstruksi dengan Lembur dan Penambahan Tenaga Kerja
}

\author{
Dinda Fardila ${ }^{\mathrm{a} *}$, Nurr Robbyatul Adwayah ${ }^{\mathrm{b}}$ \\ a Jurusan Teknik Sipil, Fakultas Teknik, Universitas Teknologi Sumbawa, NTB, 84371, Indonesia \\ ${ }^{\mathrm{b}}$ Jurusan Teknik Sipil, Fakultas Teknik, Universitas Muhammadiyah Yogyakarta, Yogyakarta, 55183, Indonesia
}

\begin{abstract}
Keywords: construction project efficiency

In the construction of a construction project, there are three main elements: time efficiency, minimal costs, and appropriate quality. This study aims to calculate changes in the cost and time of project implementation with variations in overtime and additional workforce. Data analysis using Microsoft Project 2010 program and Time-Cost Trade-Off method. The results of this study indicate that (1) the optimum time and costs due to overtime are obtained at the project age of 235 working days with a total project cost of IDR 8,438,038,832 with a project time efficiency of 5 days (2.13\%) and a project cost efficiency of IDR 3.559,695 (0.042\%). (2) The optimum time and cost due to the addition of labor is the best choice with the results obtained at the project age of 226 working days with a total project cost of IDR 8,429,832,759 with a project time efficiency of 14 days $(6.19 \%)$ and cost-efficiency. project amounting to Rp. $11,779,674(0.14 \%)$.
\end{abstract}

Kata kunci: konstruksi proyek efisiensi

\begin{abstract}
ABSTRAK
Dalam pelaksanaan pembangunan suatu proyek konstruksi, terdapat tiga unsur utama yaitu waktu yang efisien, biaya minimal dan mutu yang sesuai. Tujuan dari penelitian ini adalah menghitung perubahan biaya dan waktu pelaksanaan proyek dengan variasi lembur dan penambahan tenaga kerja. Analisis data menggunakan program Microsoft Project 2010 dan metode Time Cost Trade Off. Hasil penelitian ini menunjukkan bahwa (1) Waktu dan biaya optimum akibat lembur didapat pada umur proyek 235 hari kerja dengan total biaya proyek sebesar Rp8.438.038.832 dengan efisiensi waktu proyek sebanyak 5 hari $(2,13 \%)$ dan efisiensi biaya proyek sebesar Rp3.559.695 (0,042\%). (2) Waktu dan biaya optimum akibat penambahan tenaga kerja menjadi pilihan terbaik dengan hasil yang didapat pada umur proyek 226 hari kerja dengan total biaya proyek sebesar Rp8.429.832.759 dengan efisiensi waktu proyek sebanyak 14 hari $(6,19 \%)$ dan efisiensi biaya proyek sebesar Rp11.779.674 $(0,14 \%)$.
\end{abstract}

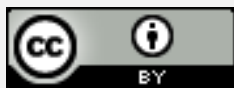

This is an open access article under the CC-BY license.

\section{Pendahuluan}

Dalam pelaksanaan pembangunan suatu proyek konstruksi, terdapat tiga unsur utama yaitu biaya, mutu dan waktu. Ketiga hal utama tersebut semuanya saling berhubungan satu sama lain, dimana suatu proyek diharapkan dapat terselesaikan dengan waktu yang sesuai jadwal yang direncanakan dengan biaya minimal dan mutu yang sudah ditetapkan dalam perencanaan proyek. Untuk memenuhi ketiga hal tersebut, perusahaan harus mempunyai metode atau cara yang dapat digunakan dalam perencanaan sebuah proyek, sehingga semua sumber daya yang dimiliki dapat dimanfaatkan secara optimal dan juga menghindarkan dari adanya denda akibat keterlambatan penyelesaian proyek. Pada penelitian ini membahas optimalisasi waktu proyek dan biaya proyek pada pelaksanaan Proyek Pembangunan Hotel Amaris Sagan Yogyakarta dengan metode penambahan jam kerja (lembur) dan metode penambahan tenaga kerja.

\subsection{Manajemen Proyek}

Dalam [1] dan [2], manajemen proyek penentuan waktu penyelesaian kegiatan ini merupakan salah satu kegiatan 
awal yang sangat penting dalam proses perencanaan karena penentuan waktu tersebut akan menjadi dasar bagi perencana yang lain, yaitu (a) penyusunan jadwal (scheduling), anggaran (budgeting), kebutuhan sumber daya manusia (man power planning), dan sumber organisasi yang lain; (b) proses pengendalian (controling).

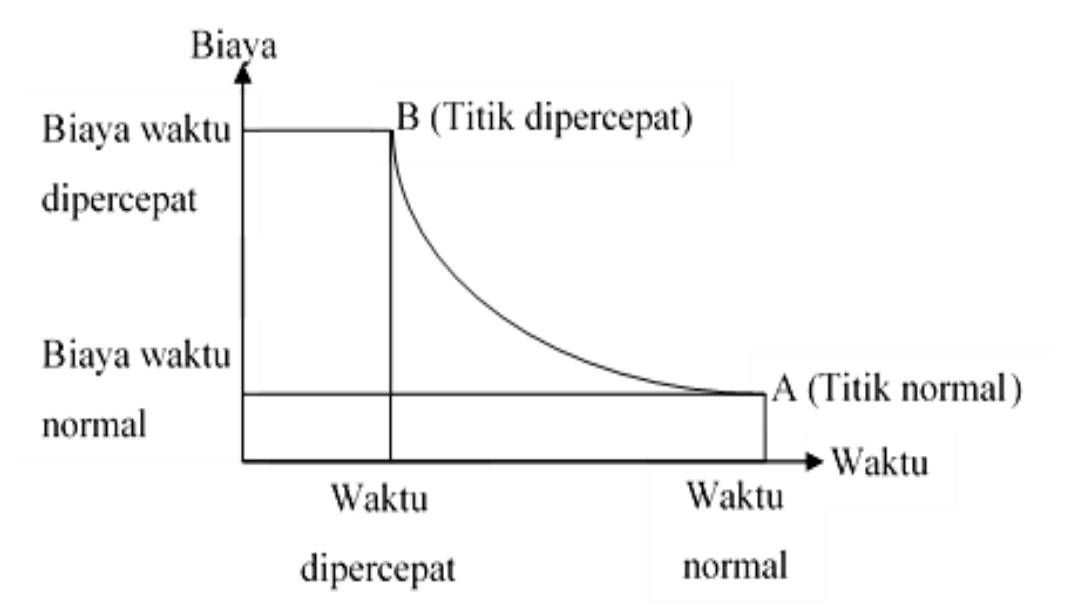

Gambar 1. Grafik hubungan waktu-biaya normal dan dipercepat untuk suatu kegiatan [3]

\subsection{Network Planning}

Suatu kegiatan harus direncanakan dengan baik agar rangkaian pekerjaan dapat terlaksana dengan optimal. Network planning adalah gambaran kejadian-kejadian dan kegiatan yang diharapkan akan terjadi dan dibuat secara kronologis serta dengan kaitan yang logis dan berhubungan antara sebuah kejadian atau kegiatan dengan yang lainnya. Dengan adanya network, manajemen dapat menyusun perencanaan penyelesaian proyek dengan waktu dan biaya yang paling efisien.

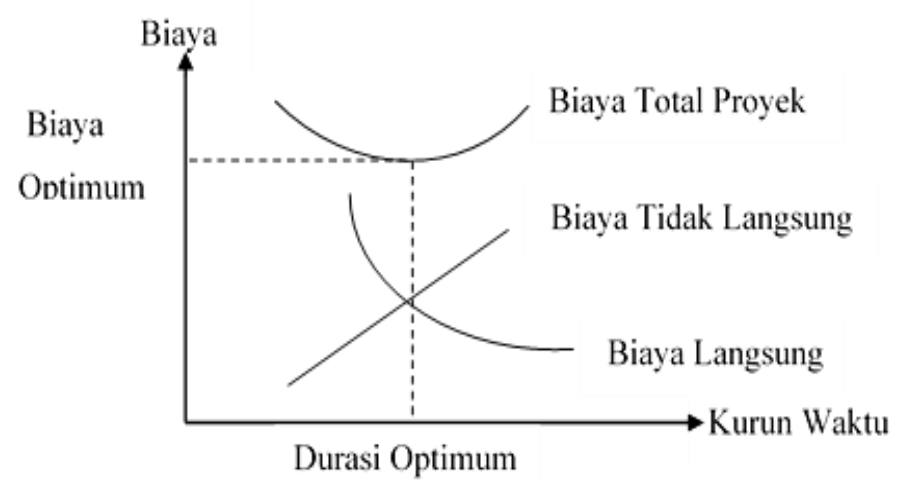

Gambar 2. Grafik hubungan waktu dengan biaya total, biaya langsung, dan biaya tak langsung [3]

\subsection{Biaya Total Proyek}

Secara umum biaya proyek konstruksi dibagi menjadi dua kelompok, yaitu biaya langsung dan biaya tidak langsung. Biaya langsung adalah biaya permanen yang melekat pada hasil akhir konstruksi seperti (a) biaya bahan / material; (b) biaya upah kerja; (c) biaya peralatan; (d) biaya subkontraktor dan lain-lain.

Inti dari perkiraan biaya secara detail adalah yang didasarkan pada penentuan jumlah material, tenaga kerja, peralatan dan jasa subkontraktor yang merupakan bagian terbesar dari biaya total proyek yaitu berkisar $85 \%$ [3] yang terdiri dari biaya perlatan sebesar $20-25 \%$, material curah
20-25\%, biaya konstruksi di lapangan yaitu tenaga kerja, material jasa subkontraktor $45-50 \%$.

Biaya tidak langsung adalah biaya tidak melekat pada hasil akhir konstruksi sebuah proyek tapi merupakan sebuah nilai yang dipungut karena proses pelaksanaan konstruksi proyek yang sering disebut dengan biaya tetap (fix cost) seperti (a) gaji staf atau pegawai tetap tim manajemen; (b) biaya konsultan (perencana dan pengawas); (c) fasilitas sementara di lokasi proyek; (d) peralatan konstruksi, (e) pajak, pungutan, asuransi dan perizinan, (f) overhead, (g) biaya tak terduga, (h) laba. Meskipun hal ini terkadang kurang mendapatkan perhatian lebih dalam proyek konstruksi, beberapa permasalahan (dispute) sering diakibatkan oleh dua hal pokok di atas [4]. 
Hubungan antara biaya dengan waktu dapat dilihat pada Gambar 1 Titik A pada gambar menunjukkan kondisi normal, sedangkan titik B menunjukkan kondisi dipercepat. Garis yang menghubungkan antar titik tersebut disebut dengan kurva waktu biaya. Gambar 1 memperlihatkan bahwa semakin besar penambahan jumlah jam kerja (lembur) maka akan semakin cepat waktu penyelesaian proyek, akan tetapi sebagai konsekuensinya maka terjadi biaya tambahan yang harus dikeluarkan akan semakin besar. Gambar 2 menunjukkan hubungan biaya langsung, biaya tak langsung dan biaya total dalam suatu grafik dan terlihat bahwa biaya optimum didapat dengan mencari total biaya proyek yang terkecil.

Jadi biaya total proyek adalah biaya langsung ditambah biaya tidak langsung. Keduanya berubah sesuai dengan waktu dan kemajuan proyek. Meskipun tidak dapat diperhitungkan dengan rumus tertentu tetapi pada umumnya makin lama proyek berjalan maka makin tinggi komulatif biaya tidak langsung yang diperlukan. Sedangkan biaya optimal didapat dengan mencari total biaya proyek yang terkendali.

\subsection{Metode CPM (Critical Path Method)}

CPM (Critical Path Method) adalah suatu metode dengan menggunakan arrow diagram dalam menentukan lintasan kritis sehingga kemudian disebut juga sebagai diagram lintasan kritis. CPM menggunakan satu angka estimasi durasi kegiatan yang tertentu (deterministic). Selain itu dalam CPM dikenal adanya EET (Earliest Event Time) dan LET (Last Event Time), serta Total Float dan Free Float. EET adalah peristiwa paling awal atau waktu tercepat dari suatu kegiatan, sedangkan LET adalah peristiwa paling akhir atau waktu paling lambat dari suatu kegiatan. Metode CPM membantu mendapatkan lintasan kritis [5] yaitu lintasan yang menghubungkan kegiatan- kegiatan kritis, atau dengan kata lain lintasan kritis adalah lintasan kegiatan yang tidak boleh terlambat ataupun mengalami penundaan pelaksanaan karena keterlambatan tersebut akan menyebabkan keterlambatan pada waktu total penyelesaian proyek.

\subsection{Metode Pertukaran Waktu dan Biaya (Time Cost Trade Off)}

Di dalam perencanaan suatu proyek disamping variabel waktu dan sumber daya, variabel biaya (cost) mempunyai peranan yang sangat penting. Biaya (cost) merupakan salah satu aspek penting dalam manjemen, dimana biaya yang timbul harus dikendalikan seminim mungkin. Pengendalian biaya harus memperhatikan faktor waktu, karena terdapat hubungan yang erat antara waktu penyelesaian proyek dengan biaya-biaya proyek yang bersangkutan.

Sering terjadi suatu proyek harus diselesaikan lebih cepat daripada waktu normalnya. Dalam hal ini pimpinan proyek dihadapkan kepada masalah bagaimana mempercepat penyelesaian proyek dengan biaya minimum. Oleh karena itu perlu dipelajari terlebih dahulu hubungan antara waktu dan biaya. Analisis mengenai pertukaran waktu dan biaya disebut dengan Time Cost Trade Off (Pertukaran Waktu dan Biaya).

Di dalam analisa time cost trade off ini dengan berubahnya waktu penyelesaian proyek maka berubah pula biaya yang akan dikeluarkan. Apabila waktu pelaksanaan dipercepat maka biaya langsung proyek akan bertambah dan biaya tidak langsung proyek akan berkurang. Beberapa macam cara yang dapat digunakan untuk melaksanakan percepatan penyeleseian waktu proyek. Cara- cara tersebut antara lain:

\subsubsection{Penambahan jumlah jam kerja (kerja lembur)}

Kerja lembur (working time) dapat dilakukan dengan menambah jam kerja perhari, tanpa menambah perkerja. Penambahan ini bertujuan untuk memperbesar produksi selama satu hari sehingga penyelesaian suatu aktivitas pekerjaan akan lebih cepat. Yang perlu diperhatikan di dalam penambahan jam kerja adalah lamanya waktu bekerja seseorang dalam satu hari. Jika seseorang terlalu lama bekerja selama satu hari, maka produktivitas orang tersebut akan menurun karena terlalu lelah.

\subsubsection{Penambahan tenaga kerja}

Penambahan tenaga kerja dimaksudkan sebagai penambahan jumlah pekerja dalam satu unit pekerja untuk melaksanakan suatu aktivitas tertentu tanpa menambahkan jam kerja. Dalam penambahan jumlah tenaga kerja yang perlu diperhatikan adalah ruang kerja yang tersedia apakah terlalu sesak atau cukup lapang, karena penambahan tenaga kerja pada suatu aktivitas tidak boleh mengganggu pemakaian tenaga kerja untuk aktivitas yang lain yang sedang berjalan pada saat yang sama. Selain itu, harus diimbangi pengawasan karena ruang kerja yang sesak dan pengawasan yang kurang akan menurunkan produktivitas pekerja. 


\subsubsection{Pergantian atau penambahan peralatan}

Penambahan peralatan dimaksudkan untuk menambah produktivitas. Namun perlu diperhatikan adanya penambahan biaya langsung untuk mobilitas dan demobilitas alat tersebut. Durasi proyek dapat dipercepat dengan pergantian peralatan yang mempunyai produktivitas yang lebih tinggi. Juga perlu diperhatikan luas lahan untuk menyediakan tempat bagi peralatan tersebut dan pengaruhnya terhadap produktivitas tenaga kerja.

\subsubsection{Pemilihan sumber daya manusia yang berkualitas}

Yang dimaksudkan dengan sumber daya manusia yang berkualitas adalah tenaga kerja yang mempunyai produktivitas yang tinggi dengan hasil yang baik. Dengan mempekerjakan tenaga kerja yang berkualitas, maka aktivitas akan lebih cepat diselesaikan.

\subsubsection{Penggunaan metode konstruksi yang efektif}

Metode konstruksi berkaitan erat dengan sistem kerja dan tingkat penguasaan pelaksana terhadap metode tersebut serta ketersedian sumber daya yang dibutuhkan. Cara-cara tersebut dapat dilaksanakan secara terpisah maupun kombinasi, misalnya kombinasi penambahan jam kerja sekaligus penambahan jumlah tenaga kerja, biasa disebut giliran (shift), dimana unit pekerja untuk pagi sampai sore berbeda dengan dengan unit pekerja untuk sore sampai malam.

\subsection{Produktivitas Pekerja}

Produktivitas didefinisikan sebagai rasio antara output dan input, atau dapat dikatakan sebagai rasio antara hasil produksi dengan total sumber daya yang digunakan. Di dalam proyek konstruksi, rasio dari produktivitas adalah nilai yang diukur selama proses konstruksi yang dapat dipisahkan menjadi biaya tenaga kerja, biaya material, metode, dan alat. Kesuksesan dari suatu proyek konstruksi salah satunya tergantung pada efektifitas pengelolaan sumber daya, dan pekerja adalah salah satu sumber daya yang tidak mudah untuk dikelola. Upah yang diberikan sangat tergantung pada kecakapan masing-masing pekerja dikarenakan setiap pekerja memiliki karakter masingmasing yang berbeda-beda satu sama lainnya.

\subsection{Pelaksanaan Lembur}

Salah satu strategi untuk mempercepat waktu penyelesaian proyek adalah dengan lembur. Lembur ini sangat sering dilakukan dikarenakan dapat memberdayakan sumber daya yang sudah ada di lapangan dan cukup dengan mengefisienkan tambahan biaya yang akan dikeluarkan oleh kontraktor. Biasanya waktu kerja normal pekerja adalah 7 jam (dimulai pukul 08.00 dan selesai pukul 17.00 dengan satu jam istirahat), kemudian jam lembur dilakukan setelah jam kerja normal selesai.

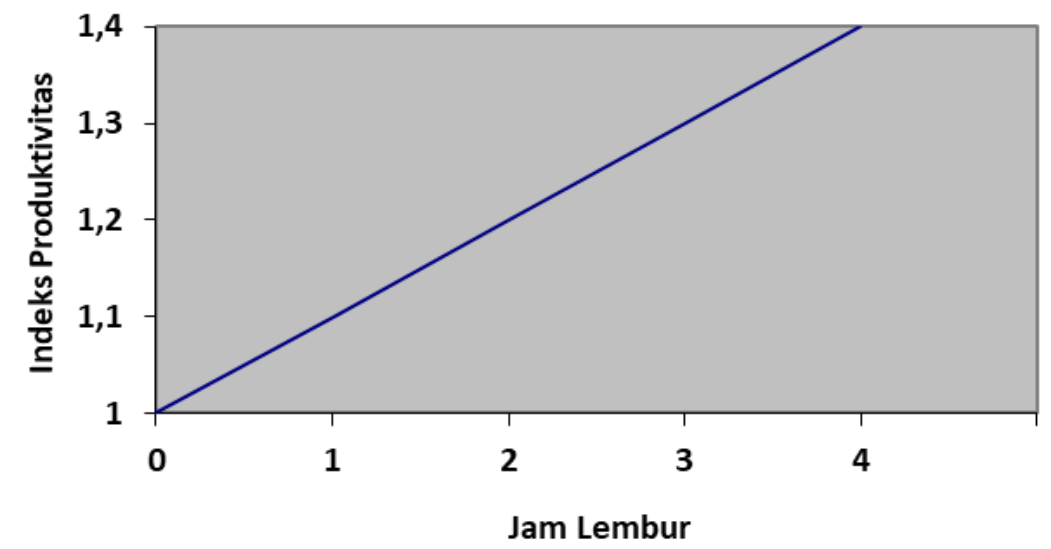

Gambar 3. Grafik Indikasi Penurunan Produktivitas Akibat Penambahan Jam Kerja [3]

Lembur bisa dilakukan dengan melakukan penambahan 1 jam, 2 jam, 3 jam, dan 4 jam sesuai dengan waktu penambahan yang diinginkan. Semakin besar penambahan jam lembur dapat menimbulkan penurunan produktivitas. Indikasi dari penurunan produktivitas pekerja terhadap penambahan jam kerja (lembur) dapat dilihat pada Gambar 3. Dari uraian di atas dapat ditulis sebagai berikut ini:
$\mathrm{Ph}: \frac{\text { volume }}{\text { durasi normal }}$

Ptj : Produktivitas Harian

keterangan:

$\mathrm{Ph}$ : produktivitas harian

Ptj: produktivitas tiap jam $(\mathrm{Ptj})$

Produktivitas harian sesudah crash: 
(Jam kerja perhari $\mathrm{x}$ Produktivitas tiap jam $)+(\mathrm{a} \times \mathrm{b} \times$ Produktivitas tiap jam)

yang mana:

$\mathrm{a}=$ lama Lembur

$\mathrm{b}=$ koefisien penurunan produktivitas akibat Lembur

Nilai koefisien penurunan produktivitas tersebut dapat dilihat pada Tabel 1 .

Tabel 1. Koefisien penurunan produktivitas

\begin{tabular}{ccc}
\hline Jam Lembur & $\begin{array}{c}\text { Penurunan Indeks } \\
\text { Produktivitas }\end{array}$ & $\begin{array}{c}\text { Prestasi Kerja } \\
(\%)\end{array}$ \\
\hline 1 jam & 0,1 & 90 \\
2 jam & 0,2 & 80 \\
3 jam & 0,3 & 70 \\
4 jam & 0,4 & 60 \\
\hline
\end{tabular}

Crash duration : $\frac{\text { volume }}{\text { produktivitas harian sesudah crash }}$

\subsection{Pelaksanaan Penambahan Tenaga Kerja}

Dalam penambahan jumlah tenaga kerja yang perlu diperhatikan adalah ruang kerja yang tersedia apakah terlalu sesak atau cukup lapang, karena penambahan tenaga kerja pada suatu aktivitas tidak boleh mengganggu pemakaian tenaga kerja untuk aktivitas yang lain yang sedang berjalan pada saat yang sama. Selain itu, harus diimbangi pengawasan karena ruang kerja yang sesak dan pengawasan yang kurang akan menurunkan produktivitas pekerja. Perhitungan untuk penambahan tenaga kerja dirumuskan sebagai berikut ini:

$\Sigma_{\mathrm{tkn}}: \frac{\text { Koefisien tenaga kerja x volume }}{\text { Durasi Normal }}$

$\Sigma_{\mathrm{tkd}}: \frac{\text { Koefisien tenaga kerja x volume }}{\text { Durasi Dipercepat }}$

keterangan:

$\sum_{\mathrm{tkn}} \quad$ jumlah tenaga kerja normal

$\sum_{\mathrm{tkd}} \quad$ : jumlah tenaga kerja dipercepat

Dari rumus di atas maka akan diketahui jumlah pekerja normal dan jumlah penambahan tenaga kerja akibat percepatan durasi proyek.

\subsection{Biaya Tambahan Pekerja (Crash Cost)}

Penambahan waktu kerja akan menambah besar biaya untuk tenaga kerja dari biaya normal tenaga kerja. Upah penambahan kerja bervariasi. Pada penambahan waktu kerja satu jam pertama, pekerja mendapatkan tambahan upah 1,5 kali upah perjam waktu normal dan pada penambahan jam kerja berikutnya maka pekerja akan mendapatkan 2 kali upah perjam waktu normal [6].
Perhitungan untuk biaya tambahan pekerja akibat jam lembur dapat dirumuskan sebagai berikut ini:

Normal upah pekerja perhari $=$ Produktivitas harian $\times$ Harga satuan upah pekerja

Normal upah pekerja perjam $=$ Produktivitas perjam $\times$ Harga satuan upah pekerja

Biaya lembur pekerja $=1,5 \times$ upah sejam normal untuk penambahan jam kerja (lembur) pertama $+2 \times \mathrm{n} \times$ upah sejam normal untuk penambahan jam kerja (lembur) berikutnya

dengan:

$\mathrm{n}=$ jumlah penambahan jam kerja (lembur)

Crash cost [7] pekerja perhari dihitung dengan persamaan:

$($ Jam kerja perhari $\times$ Normal cost pekerja $)+(n \times$ Biaya lembur perjam)

Cost slope : $\frac{\text { Crash cost } x \text { Normal cost }}{\text { Durasi normal - Durasi crash }}$

Normal ongkos pekerja perhari sesuai dengan harga satuan setiap daerah. Perhitungan untuk biaya tambahan akibat penambahan tenaga kerja dapat dirumuskan sebagi berikut: Biaya penambahan pekerja : Jumlah pekerja $\times$ upah normal pekerja perhari

Crash cost pekerja $=($ Biaya total pekerja yang dipercepat

- Biaya total pekerja normal)

Cost slope : $\frac{\text { Crash cost } x \text { Normal cost }}{\text { Durasi normal - Durasi crash }}$

\subsection{Biaya Denda}

Keterlambatan penyelesaian proyek akan menyebabkan kontaktor terkena sanksi berupa denda yang telah disepakati dalam dokumen kontrak. Besarnya biaya denda umumnya dihitung sebagai berikut:

Total denda : total waktu akibat keterlambatan $\times$ denda perhari akibat keterlambatan

keterangan: denda perhari akibat keterlambatan sebesar 1 permil dari nilai kontrak.

\subsection{Program Microsoft Project}

Microsoft Project merupakan software administrasi proyek yang digunakan untuk melakukan perencanaan, pengelolaan, pengawasan dan pelaporan data dari suatu proyek. Kemudahan penggunaan dan keleluasaan lembar kerja serta cakupan unsur-unsur proyek menjadikan software ini sangat mendukung proses administrasi sebuah proyek. 
Microsoft Project memberikan unsur-unsur manajemen proyek yang sempurna dengan memadukan kemudahan pengguna, kemampuan, dan fleksibilitas sehingga penggunanya dapat mengatur proyek lebih efesien dan efektif. Pengelolaan proyek konstruksi membutuhkan waktu yang panjang dan ketelitian yang tinggi. Microsoft Project dapat menunjang dan membantu tugas pengelolaan sebuah proyek konstruksi sehingga menghasilkan suatu data yang akurat.

Keunggulan Microsoft Project adalah kemampuannya menangani perencanaan suatu kegiatan, pengorganisasian dan pengendalian waktu serta biaya yang mengubah input data menjadi sebuah output data sesuai tujuannya. Input mencakup unsur-unsur manusia, material, mata uang, mesin/alat dan kegiatan-kegiatan. Seterusnya diproses menjadi suatu hasil yang maksimal untuk mendapatkan informasi yang diinginkan sebagai pertimbangan untuk pengambilan keputusan. Dalam proses diperlukan perencanaan, pengorganisasian, dan pengendalian.

Keuntungan Microsoft Project adalah dapat melakukan penjadwalan produksi secara efektif dan efesien, dapat diperoleh secara langsung informasi biaya selama periode, mudah dilakukan modifikasi dan penyusunan jadwal produksi yang tepat akan lebih mudah dihasilkan dalam waktu yang cepat.

Beberapa jenis metode manajemen proyek yang dikenal saat ini, antara lain CPM (Critical Path Method), PERT (Program Evaluation Review Technique), dan Gantt Chart. Microsoft Project adalah penggabungan dari ketiganya. Microsoft project juga merupakan sistem perencanaan yang dapat membantu dalam menyusun penjadwalan (scheduling) suatu proyek atau rangkaian pekerjaan. Microsoft project juga membantu melakukan pencatatan dan pemantauan terhadap pengguna sumber daya (resource), baik yang berupa sumber daya manusia maupun yang berupa peralatan.

Tujuan penjadwalan dalam Microsoft Project yaitu (a) mengetahui durasi kerja proyek; (b) membuat durasi optimum; (c) mengendalikan jadwal yang dibuat; (d) mengalokasikan sumber daya (resources) yang digunakan. Komponen yang dibutuhkan pada jadwal yaitu (a) kegiatan (rincian tugas, tugas utama); (b) durasi kerja untuk tiap kegiatan; (c) hubungan kerja tiap kegiatan; (d) resources (tenaga kerja pekerja dan bahan).

Microsoft Project dapat digunakan untuk (a) mencatat kebutuhan tenaga kerja pada setiap sektor; (b) mencatat jam kerja para pegawai, jam lembur; (c) menghitung pengeluaran sehubungan dengan ongkos tenaga kerja, memasukkan biaya tetap, menghitung total biaya proyek; (d) Membantu mengontrol pengguna tenaga kerja pada beberapa pekerjaan untuk menghindari over allocation (kelebihan beban pada penggunaan tenaga kerja). Microsoft project memiliki beberapa macam tampilan layar, namun sebagai default setiap kali membuka file baru, yang akan ditampilkan adalah Gantt Chart View. Tampilan Gantt Chart View dapat dilihat pada Gambar 4.

\section{Metode Penelitian}

\subsection{Tahap dan Prosedur Penelitian}

Suatu penelitian harus dilaksanakan secara sistematis dan dengan urutan yang jelas dan teratur, sehingga akan diperoleh hasil sesuai dengan yang diharapkan. Oleh karena itu, pelaksanaan penelitian ini dibagi dalam beberapa tahap, yaitu: (a) tahap persiapan; (b) tahapan pengumpulan data; (c) analisis percepatan dengan aplikasi program dan metode time cost trade off ; dan (d) kesimpulan yang telah ditetapkan berdasarkan kepada tujuan penelitian.

\subsection{Pengumpulan Data}

Pengumpulan data atau informasi dari suatu pelaksanaan proyek konstruksi sangat bermanfaat untuk evaluasi optimasi waktu dan biaya secara keseluruhan. Data yang diperlukan adalah data sekunder yaitu data yang diperoleh dari instansi yang terkait seperti kontraktor, konsultan pengawas, dan lain-lain.

Variabel yang sangat mempengaruhi dalam pengoptimasian waktu dan biaya pelaksanaan proyek ini adalah variabel waktu dan variabel biaya. Data yang mempengaruhi variabel waktu diperoleh dari kontraktor PT. B. Data yang dibutuhkan untuk variabel waktu adalah: (a) Data cumulative progress (kurva-S), meliputi: Jenis kegiatan, persentase kegiatan, durasi kegiatan. Sedangkan data-data yang mempengaruhi variabel biaya diperoleh dari kontraktor PT. B. Data-data yang diperlukan dalam variabel biaya antara lain: (a) Daftar rencana anggaran biaya (RAB) penawaran, meliputi jumlah biaya normal, durasi normal; (b) Daftar-daftar harga bahan dan upah; (c) Analisis harga satuan. Sedangkan, data proyek yang diperlukan untuk pembuatan laporan, meliputi (a) Rencana Anggaran Biaya (RAB), (b) analisa harga satuan bahan proyek, (c) time schedule, (d) biaya tidak langsung. 


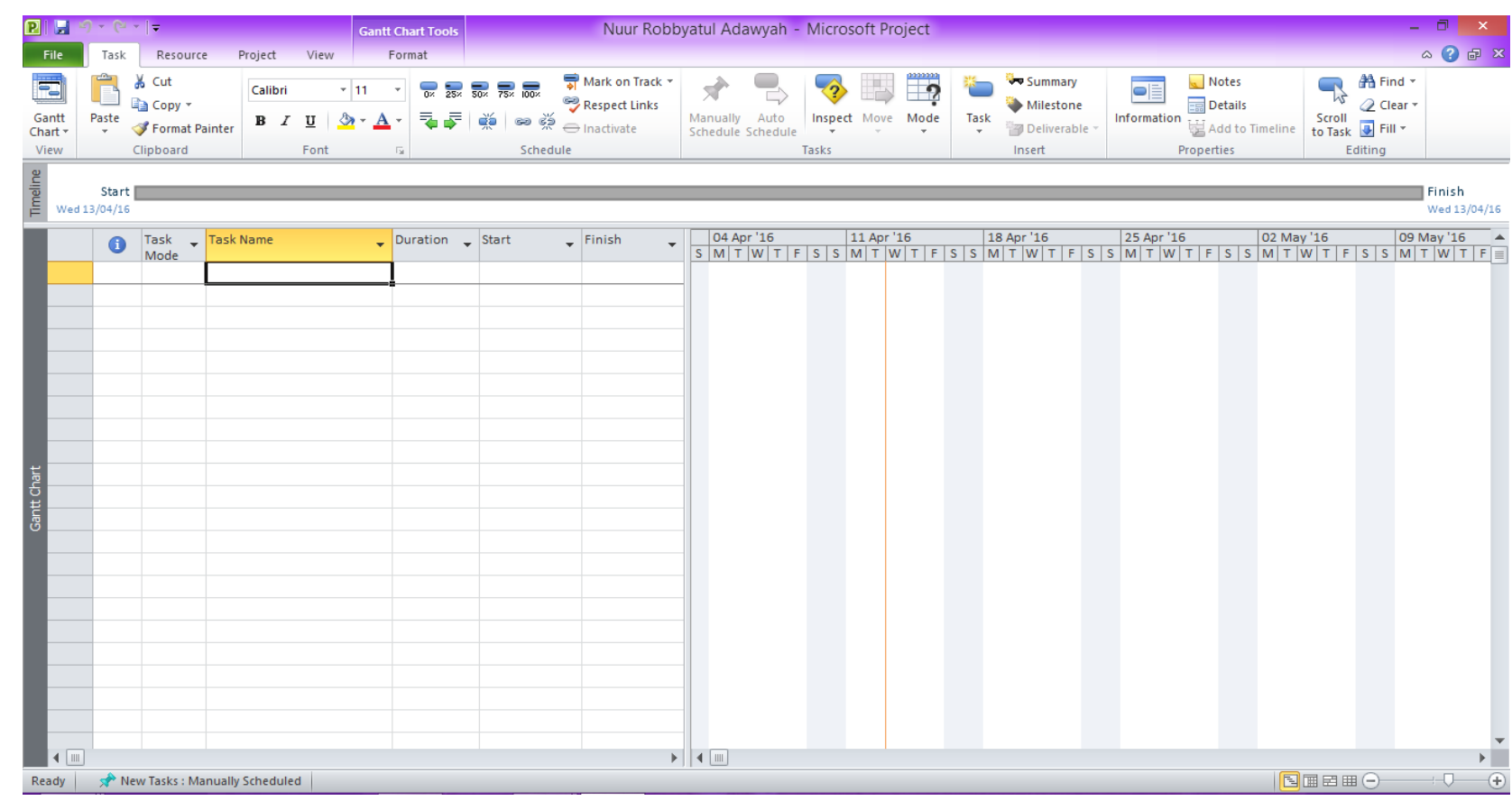

Gambar 4. Tampilan layar Gantt Chart View

\subsection{Analisis Data}

Pertama dibuat AHSP baru yang lebih rinci karena AHSP yang di dapat dari kontraktor PT. B tidak ada rincian koefisien dan harga satuan untuk masing-masing tenaga kerja. Pada AHSP yang di dapat dari kontraktor PT. B upah untuk tenaga kerja langsung digabung menjadi upah kerja. Selanjutnya dibuat RAB yang sesuai dengan AHSP yang telah dibuat. AHSP dan RAB baru ini yang selanjutnya digunakan dalam analisis data. Analisis data dilakukan dengan bantuan program Microsoft Project 2010, Metode Time Cost Trade Off dan Microsoft Excel 2010. Dengan menginputkan data yang terkait untuk dianalisis ke dalam program Microsoft Project 2010, maka nantinya akan dikalkulasi secara otomatis sesuai dengan rumus-rumus kalkulasi yang telah dibuat oleh program ini. Hasil penginputan data adalah lintasan kritis.

Setelah lintasan kritis didapat selanjutnya dianalisis setiap kegiatan pekerja yang berada di lintasan kritis dengan metode time cost trade off [8] yaitu penambahan jam lembur dan tenaga kerja yang juga dibantu dengan Microsoft Excel 2010 untuk mempermudah analisis dan perhitungan. Hasil dari analisis tersebut adalah percepatan durasi dan kenaikan biaya akibat percepatan durasi dalam setiap kegiatan yang dipercepat. Kenaikan biaya ini disebabkan karena penambahan jam lembur dan tenaga kerja.

\section{Hasil dan Pembahasan}

\subsection{Data Umum Proyek}

Adapun gambaran umum dari Proyek Pembangunan Hotel Amaris Sagan Yogyakarta ini adalah sebagai berikut:

Tabel 2. Data umum proyek

\begin{tabular}{clc}
\hline No & & Keterangan \\
\hline 1 & owner & PT. A \\
2 & kontraktor & PT. B \\
3 & anggaran total & Rp8.235.720.555,54 \\
4 & anggaran baseline & \\
5 & waktu pelaksanaan & 240 hari kerja \\
\hline
\end{tabular}

\subsection{Kegiatan-Kegiatan Kritis}

Alasan - alasan pemilihan item kegiatan yang ada dalam kegiatan krirtis yaitu (a) kegiatan kritis yang terpilih memilik pekerja sehingga bisa dicrashing; (b) pada kegiatan kritis terpilih dapat dilakukan percepatan dengan penambahan jam lembur atau dengan penambahan jumlah tenaga kerja. Jika dilakukan penambahan tenaga kerja pada kegiatan kritis yang lain maka jumlah tenaga kerja tidak akan bertambah karena kegiatan kritis tersebut hanya memiliki indeks tenaga kerja yang kecil. 
Tabel 2. Daftar Kegiatan Kritis

\begin{tabular}{clc}
\hline Kode & \multicolumn{1}{c}{ Item Pekerjaan } & $\begin{array}{c}\text { Durasi } \\
\text { (Hari) }\end{array}$ \\
\hline A & Galian Tanah, Sirtu, & 12 \\
& Pecah Pancang & \\
C & Buang tanah keluar site & 12 \\
D & Lantai kerja tebal 5 cm & 12 \\
E & Pile cap & 12 \\
F & Tie Beam & 12 \\
G & Plat/Slab semi basement & 12 \\
H & Dinding semi basement & 12 \\
J & Tangga & 6 \\
L & Kolom & 12 \\
AD & Kolom & 12 \\
AH & Balok & 12 \\
AL & Plat lantai & 12 \\
AN & Kolom & 12 \\
AO & Tangga & 6 \\
AQ & Plat lantai & 12 \\
AR & balok & 12 \\
\hline
\end{tabular}

\subsection{Penerapan Metode Time Cost Trade Off Penambahan Jam Kerja (Waktu Lembur)}

Dalam perencanaan penambahan jam kerja lembur memakai 8 jam kerja normal dan 1 jam istirahat (08.0017.00), sedangkan kerja lembur dilakukan setelah waktu kerja normal (17.00-18.00). Berdasarkan [6] standar upah untuk lembur yaitu (a) waktu kerja lembur hanya dapat dilakukan paling banyak 3 (jam) dalam 1 (satu) hari dan 14 (empat belas) jam dalam 1 (satu) minggu; (b) memberikan makanan dan minuman sekurang-kurangnya 1.400 kalori apabila kerja lembur dilakukan selama 3 jam atau lebih; (c) untuk kerja lembur pertama harus dibayar sebesar 1,5 kali upah sejam; (d) untuk setiap jam kerja lembur berikutnya harus dibayar upah sebesar 2 kali lipat upah satu jam.

Adapun salah satu contoh perhitungannya pada Pekerjaan Galian Tanah, Sirtu, Pecah Pancang sebagai berikut (lihat Tabel 3):

Tabel 3. Data umum proyek

\begin{tabular}{rll}
\hline No & \multicolumn{2}{c}{ Keterangan } \\
\hline 1 & volume & $2.594,67 \mathrm{~m}^{3}$ \\
2 & Durasi normal & 12 hari \\
3 & Durasi normal (jam) & $21.8=96$ \\
4 & produktivitas jam normal & $27.03 \mathrm{~m}^{3} / \mathrm{jam}$ \\
5 & Maksimal crashing & 1 hari \\
\hline
\end{tabular}

Nilai maksimal crashing dihitung dengan cara:

$$
\text { maksimal crashing: } \frac{2594.67}{(27.03 \times 8)+(1 \times 0.9 \times 27.03)}
$$

Maka maksimal crashing $=12-11=1$ hari

Upah lembur perjam:

Mandor $: 8.750 \times 1,5=\mathrm{Rp} 13125$

Pekerja $: 5.938 \times 1,5=\mathrm{Rp} 8.906$

Upah kerja

Pekerja : $(162,17 \times 1$ jam $\times$ Rp8.906,00 $)$

: Rp1.444.301,00

Mandor : $(5,41 \times 3$ jam $\times$ Rp13.125,00)

$$
\text { : Rp70.948,00 }
$$

Total Upah lembur : Rp1.444.301,00+ Rp70.948,00

: Rp1.515.249,00

Biaya Normal : : Rp. 97.041 .375

Biaya percepatan : Rp1.515.249,00+Rp97.041.375,00

: Rp 98.556.624,00

slope biaya perhari : $\frac{\text { total upah lembur }}{\text { maksimal crashing }}$

: Rp1.515.249,00

Slope biaya setelah crashing: Rp1.515.249,00×1 hari

$$
\text { : Rp1.515.249,00 }
$$

Waktu dan biaya optimum [9] akibat lembur didapat pada umur proyek 235 hari kerja dengantotalbiaya proyek sebesar Rp8.438.038.832 dengan efisiensi waktu proyek sebanyak 5 hari $(2,13 \%)$ dan efisiensi biaya proyek sebesar Rp3.559.695 (0,042\%) pada Tabel 4.:

Tabel 4. Efisiensi proyek

\begin{tabular}{lc}
\hline \multicolumn{1}{c}{ Keterangan } & $(\%)$ \\
\hline Efisiensi waktu: 5 hari & 2.13 \\
Efisiensi biaya & 0.042 \\
\hline
\end{tabular}

Untuk perhitungan biaya total akibat jam lembur dapat dilihat pada Tabel 6 sedangkan Grafik biaya total, grafik biaya langsung dan grafik biaya tidak langsung [10] akibat jam lembur dapat dilihat pada Gambar 5.

Penambahan Tenaga Kerja Adapun salah satu contoh perhitungannya adalah Pekerjaan Galian Tanah, Sirtu, Pecah Pancang.

Volume : $2594,674 \mathrm{~m}^{3}$

Durasi normal : 12 hari 


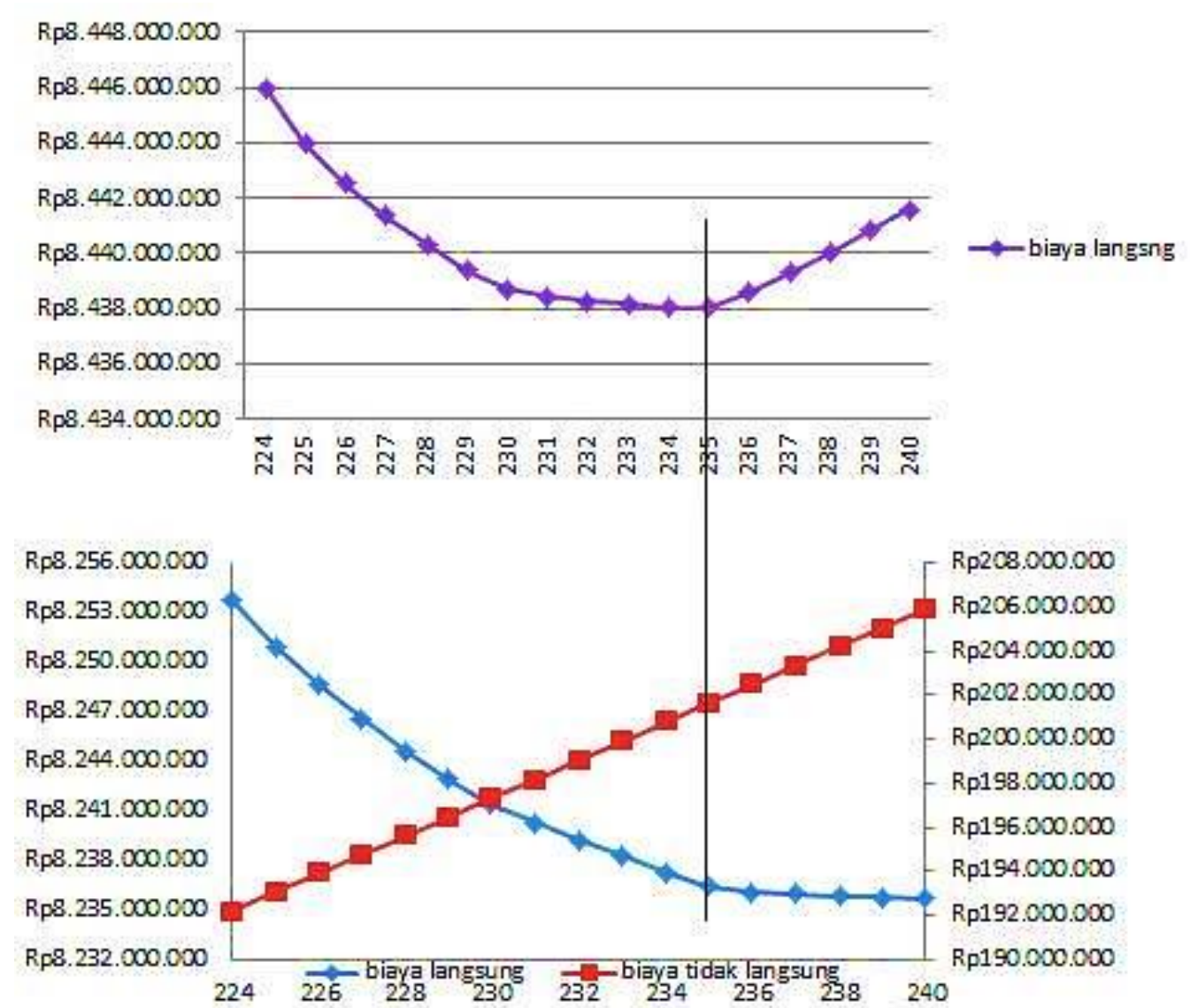

Gambar 5. Grafik biaya langsung dan grafik biaya tidak langsung akibat jam lembur

Tabel 5. Hasil maksimal crashing

\begin{tabular}{cccrr}
\hline Kode & Durasi Normal & Durasi Percepatan & Biaya Normal (Rp) & Biaya Percepatan $(\mathrm{Rp})$ \\
\hline A & 12 & 11 & 97.041 .375 & 98.556 .624 \\
C & 12 & 11 & 2.318 .900 & 2.355 .107 \\
D & 12 & 11 & 34.555 .387 & 34.647 .300 \\
E & 12 & 11 & 202.631 .156 & 203.643 .107 \\
F & 12 & 11 & 159.767 .713 & 160.742 .986 \\
G & 12 & 11 & 375.397 .723 & 377.182 .244 \\
H & 12 & 11 & 131.578 .209 & 131.916 .733 \\
J & 6 & 5 & 11.389 .985 & 11.516 .150 \\
L & 12 & 11 & 181.572 .633 & 182.688 .817 \\
AD & 12 & 11 & 166.133 .337 & 167.130 .871 \\
AH & 12 & 11 & 460.155 .182 & 463.018 .375 \\
AL & 12 & 11 & 356.513 .295 & 358.421 .534 \\
AN & 12 & 11 & 148.155 .195 & 149.026 .988 \\
AO & 6 & 5 & 11.395 .508 & 11.518 .534 \\
AQ & 12 & 11 & 380.820 .092 & 382.870 .862 \\
AR & 12 & 11 & 373.469 .010 & 375.764 .210 \\
\hline
\end{tabular}

Kapasitas tenaga kerja per $1 \mathrm{~m}^{3}$ adalah

Pekerja : 162,167 Oh@ Rp47.500

Tukang : 5,406 Oh @ Rp70.000

Jumlah tenaga kerja (Jtk) dihitung dengan persamaan (16):
Jtk: $\frac{\text { koefisien tenaga kerja volume }}{\text { durasi normal }}$

Untuk pekerjaan galian tanah, sirtu, pecah pancang pada penelitian ini terdiri dari 4 bagian yaitu: 
Tabel 6. Analisis upah kerja

\begin{tabular}{lcccc}
\hline Jenis Pekerjaan & Pekerja & Mandor & $\begin{array}{c}\text { Upah pekerja } \\
(\mathrm{Rp})\end{array}$ & $\begin{array}{c}\text { Upah mandor } \\
\text { (Rp) }\end{array}$ \\
\hline Semi basement & 103.57 & 3.45 & & \\
Pile cap, tie beam, pit lift & 14.34 & 0.48 & & \\
Ground water tank & 32.79 & 1.09 & 7.703 .075 & 378.700 \\
Sawage treatment plant & 11.47 & 0.38 & & \\
$\quad$ total & 162.17 & 5.41 & & \\
\hline
\end{tabular}

Jadi upah normal tenaga kerja selama 12 hari adalah: $($ Rp7.703.075 + Rp378.700) $\times 12$ hari : Rp 96.981.300

Biaya Material : Total Upah Normal - Upah

Normal Tenaga Kerja : Rp.97.041.375 - Rp96.981.300

: Rp 60.075,00
Pekerjaan ini akan dipercepat dengan durasi percepatan 1 hari, adapun perhitungannya adalah sebagai berikut:

$$
\begin{array}{ll}
\text { Volume } & : 2594,674 \mathrm{~m}^{3} \\
\text { Crashing } & : 1 \text { hari } \\
\begin{array}{l}
\text { Durasi dipercepat } \\
\text { tenaga kerja. }
\end{array} & : 12-1=11 \text { hari Perhitungan jumlah }
\end{array}
$$

Tabel 7. Percepatan pekerjaan

\begin{tabular}{llcccc}
\hline No & Jenis Pekerjaan & Pekerja & Mandor & $\begin{array}{c}\text { Upah pekerja } \\
\text { (Rp) }\end{array}$ & $\begin{array}{c}\text { Upah mandor } \\
\text { (Rp) }\end{array}$ \\
\hline 1 & Semi basement & 112.98 & 3.77 & & \\
2 & $\begin{array}{l}\text { Pile cap, tie beam, } \\
\text { pit lift }\end{array}$ & 15.65 & 0.52 & & \\
3 & $\begin{array}{l}\text { Ground water tank } \\
4\end{array}$ & 35.77 & 1.19 & $8.403 .700,00$ & $413.000,00$ \\
& $\begin{array}{l}\text { Sawage treatment } \\
\text { plant total }\end{array}$ & 12.51 & 0.42 & & \\
& & 176.92 & 5.90 & & $96.983 .700,00$ \\
\hline
\end{tabular}

Jadi Total Biaya Percepatan Tenaga Kerja adalah $=$ Upah Percepatan Tenaga Kerja + Biaya Material = Rp96.983,70 + Rp 60.075,00 = Rp97.043.775,00 slope biaya per - hari: $\frac{97.043,78-97.041,38}{(12-11)}$

slope biaya selama 1 hari $=\mathrm{Rp} 2400 \times 1$ hari $=\mathrm{Rp} 2400$

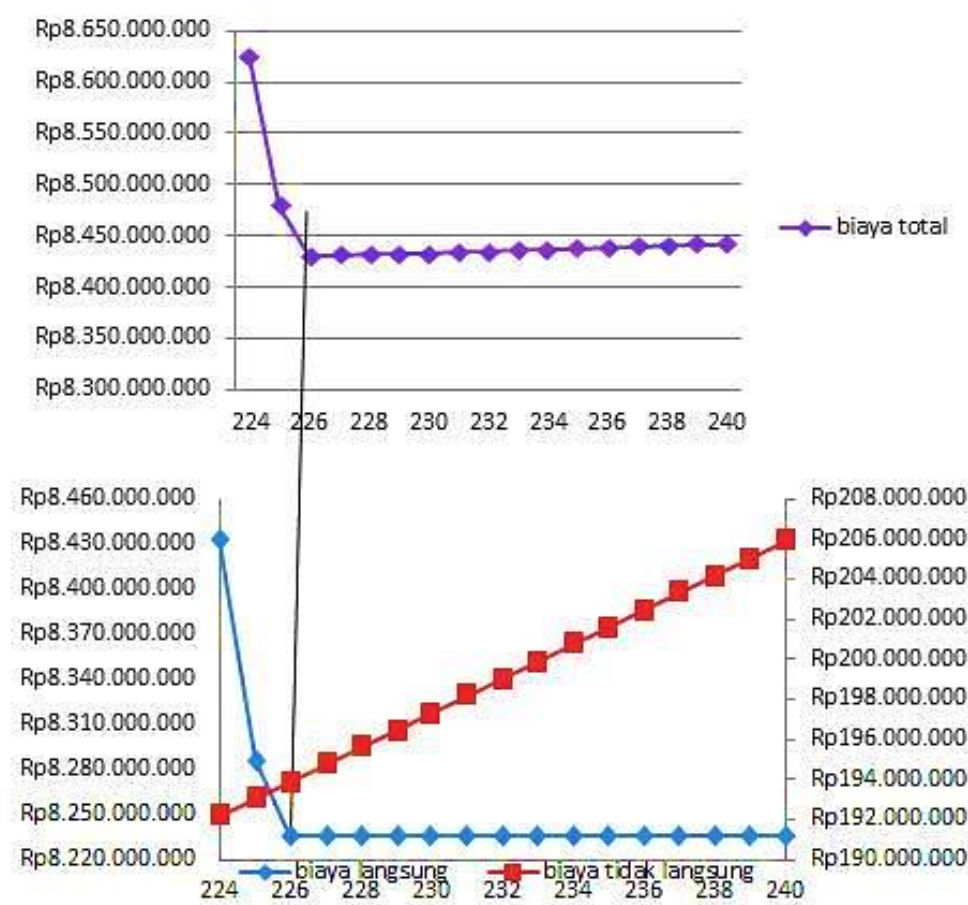

Gambar 5. Grafik biaya langsung dan grafik biaya tidak langsung akibat jam lembur 
Diperoleh biaya total proyek dengan durasi atau umur proyek yang optimal yakni pada umur proyek 226 hari kerja dengan total biaya proyek yang optimum sebesar Rp8.429.832.759. Dengan persentase efisiensi waktu dan biaya pada Tabel 8 .

Table 8. Efisiensi proyek konstruksi

\begin{tabular}{|c|c|}
\hline Efisiensi proyek & $(\%)$ \\
\hline Waktu & 6.19 \\
\hline Biaya & 0.14 \\
\hline
\end{tabular}

\section{Simpulan}

Dari data serta hasil analisis dan pembahasan yang dilakukan pada Proyek Pembangunan Hotel Amaris Sagan Yogyakarta dapat disimpulkan bahwa: (a) Waktu dan biaya optimum akibat lembur didapat pada umur proyek 235 hari kerja dengan total biaya proyek sebesar Rp8.438.038.832 dengan efisiensi waktu proyek sebanyak 5 hari $(2,13 \%)$ dan efisiensi biaya proyek sebesar Rp3.559.695(0,042\%); (b) Waktu dan biaya optimum akibat penambahan tenaga kerja didapat pada umur proyek 226 hari kerja dengan total biaya proyek sebesar Rp8.429.832.759 dengan efisiensi waktu proyek sebanyak 14 hari $(6,19 \%)$ dan efisiensi biaya proyek sebesar Rp11.779.674 (0,14\%); (c) Pilihan terbaik adalah dengan penambahan tenaga kerja karena menghasilkan efisiensi waktu dan biaya yang paling tinggi dengan efisiensi waktu proyek sebanyak 14 hari $(6,19 \%)$ dan efisiensi biaya proyek sebesar Rp11.779.674(0,14\%); (d) Biaya mempercepat durasi proyek (lembur atau penambahan tenaga kerja) lebih murah dibandingkan dengan biaya yang harus dikeluarakan apabila proyek mengalami keterlambatan dan dikenakan denda.

\section{Daftar Rujukan}

[1] M. R. Aulia, "Optimasi Biaya dan Waktu Proyek Konstruksi dengan Penambahan Jam Kerja dibandingkan dengan Tenaga Kerja Menggunakan Metode Time Cost Trade Off," Universitas Muhammadiyah Yogyakarta, 2015.

[2] I. Soeharto, Manajemen Proyek dari Konseptual Sampai Operasional. Yogyakarta: Erlangga, 1997.

[3] G. J. Ritz, Total Construction Project Management. New York: McGrawHill, Inc, 1994.

[4] D. A. U. Ilma, F. Fitriyanti, F. Ma'arif, N. Baldah, and B. Utoyo, "State of the art perselisihan kontrak konstruksi di Indonesia," INERSIA, vol. 16, no. 2, pp. 158-170, 2020, doi: https://doi.org/10.21831/inersia.v16i2.36901.

[5] A. Khalim, H. U. Ghifarsyam, N. Rozy, and F. Ma'arif, "Scheduling design of Jakarta-Cikampek II elevated toll road project (P. 186-P. 187)," J. Eng. Appl. Technol., vol. 2, no. 1, 2021, doi: https://doi.org/10.21831/jeatech.v1i2.34957.

[6] Kementerian Tenaga Kerja dan Transmigrasi Republik Indonesia, Keputusan Menteri Tenaga Kerja dan Transmigrasi Republik Indonesia. Nomor Kep.102/Men/VI/2004 tentang Waktu Kerja Lembur dan Upah Kerja Lembur. Indonesia, 2004.

[7] A. W. Laksana, H. S. Prasetyo, M. A. Wibowo, and A. Hidayat, "Optimalisasi waktu dan biaya proyek dengan analisa crash program," J. Karya Tek. Sipil, vol. 3, no. 3, pp. 747-759, 2014.

[8] N. Buluatie, "Optimalisasi Biaya dan Waktu dengan Metode Time Cost Trade Off," Universitas Gorontalo, 2013.

[9] A. Frederika, "Analisis percepatan pelaksanaan dengan menambah jam kerja optimum pada proyek konstruksi (Studi kasus: proyek pembangunan super villa, Peti Tenget-Badung)," J. Ilm. Tek. Sipil, vol. 14, no. 2, 2010.

[10] W. Nuswantoro, A. B. P. Gawei, and Wiwinto, "Studi praktik estimasi biaya tidak langsung pada proyek konstruksi oleh kontraktor di kota Palangka Raya," 2019. 